\title{
COMUNICAÇÃO
}

\section{O QUE SE DEVE FAZER QUANDO SE SUSPEITA DO DIAGNÓSTICO DE SÍNDROME DE IMUNODEFICIÊNCIA ADQUIRIDA?}

\section{Y. Meunier}

O diagnóstico de sindrome de imunodeficiência adquirida (SIDA) só poderá ser estabelecido através de um conjunto de dados clínicos, epidemiológicos, biológicos e imunológicos. Após uma revisão da literatura estabelecemos os critérios que permitiam evitar os excessos ou faltas de diagnósticos, na maioria das vezes devidos à falta de referências precisas.

Certas caracteristicas permitem definir a SIDA:

1. Deve suspeitar-se desta entidade no caso de um paciente que apresenta um déficit da imunidade celular e uma ou mais das infecções oportunistas, a seguir:

- Parasitárias: pneumocistose pulmonar, meningoencefalite toxoplásmica, criptosporidiose digestiva, estrongiloidiase disseminada.

- Micoses: candidíase do esôfago, aspergilose do sistema nervoso central (SNC), criptococose do SNC.

- Bacterianas: micobacterioses atípicas.

- Virais: infecção do pulmão, do SNC ou do trato digestivo pelo citomegalovirus; infecção do SNC, do pulmão, do trato digestivo ou envolvimento mucocutâneo extenso pelo vírus herpes; leucoencefalite multifocal progressiva.

Assim como outras infecções: legionelose, listeriose, nocardiose, tuberculose multivisceral evolutiva, salmoneloses reincidentes.

2. Não se deve incluir um individuo que tenha recebido corticoterápico ou imunossupressores nos 3 meses que antecedem o primeiro sintoma ou:

- Alguém tendo linfoma de Hodgkin ou outro, mieloma ou leucemia linfóide (pelo contrário o linfoma cerebral isolado pode ser sugestivo de SIDA).

Endereço para correspondência: Dr. Y. Meunier, Departamento de Medicina Tropical e Parasitologia do Prof. Gentilini, Pavillon Laveran, Hôpital de la Salpétrière. 47, boulevard de l'Hôpital, 75013 Paris, France.

Recebido para publicação em 20/2/1984.
- Alguém tendo mais de 60 anos ou menos de 28 dias.

- Uma pessoa com déficit imunitário congênito.

3. Verificar se o paciente pertence a um grupo de risco:

- Homossexualidade (principal);

- Toxicomania por via intravenosa;

- Hemofilia;

- Origem geográfica (Haiti; África Equatorial: Zaire, Congo, Mali; Europa Central; Bacia do Mediterrâneo; Nova Iorque; São Francisco).

4. Verificar se ele apresenta as manifestações clinicas seguintes, num periodo de três meses:

- Adenopatias atingindo duas áreas ganglionares sem contigüidade (exceto os gânglios inguinais);

- Perda de peso superior ou igual a $10 \%$ do peso corpóreo ou sete quilogramas;

- Febre acima de $38^{\circ} \mathrm{C}$ durante pelo menos 3 semanas no decorrer do periodo de 3 meses;

- Suores noturnos;

- Candidíase oral ou dermatite seborréica;

- Astenia;

- Diarréia persistindo mais de um mês.

5. Tentar identificar as modificações biológicas seguintes:

- Diminuição dos linfócitos T “auxiliares” abaixo de 600.

- Diminuição da relação T "auxiliar" abaixo de 1.

$$
\text { T supressor }
$$

- Leucopenia inferior a 4.000 ou trombocitopenia inferior a 100.000 com linfopenia abaixo de 1.500 .

- Anergia cutânea ao multiteste (tuberculina, candidina, varidase).

- Diminuição das respostas proliferativas dos linfócitos abaixo de $50 \%$ do normal.

- Aumento das $B_{2}$-microglobulinas acima de $3 \mathrm{mg} / 1$.

- Presença de complexos imunes circulantes. 
Meunier $Y$. O que se deve fazer quando se suspeita do diagnostico de sindrome de imunodeficiência adquirida. Revista da Sociedade Brasileira de Medicina Tropical 17: 107-108, Abr-Jun, 1984

Para reunir os critérios de inclusão na SIDA um individuo deve apresentar pelo menos duas dessas manifestaçōes clinicas e duas dessas anomalias biológicas.

6. Quando o diagnóstico de SIDA for estabelecido se deve realizar um inquérito entre os contatos e controle assim definidos:

- O individuo contato teve, pelo menos, cinco relaçōes sexuais com um doente com SIDA.

- O controle vive com um doente com SIDA mas sem com ele ter relações sexuais.

Além disso, deve-se verificar se o doente tem doado sangue e a seguir tentar identificar as pessoas que receberam seu sangue.

7. Deve-se, sistematicamente, encaminhar o paciente a um departamento especializado para um estudo mais amplo: biológico, imunitário, endoscopia alta e baixa, estudo do trânsito do intestino delgado, biopsia medular, exame parasitológico das fezes, se for necessário uma biópsia de gânglio com um "check-up" particular em caso de febre e localização infecciosa incluindo uma punção - bióspia do figado. O paciente deve ser submetido a exames de controle sorológicos mensais. Assim que o diagnóstico for feito o doente receberá um tratamento especifico e/ou um tratameito "de base" experimental em função desse diagnóstico (interfon $\alpha$, timuline etc).

Finalmente, e sobretudo, os especialistas deverão procurar o possivel agente etiológico dessa infecção (retrovirus c: LAV* ou HTLV**).

* Linfadenopathy-associated-virus.

** Human T cell leukemia lymphoma virus 